\title{
Occurrence and Some Ecological Aspects of the Golden Jackal (Canis aureus Linnaeus, 1758) in the Gaza Strip, Palestine
}

\author{
Abdel Fattah N. Abd Rabou ${ }^{*}$, Kamal E. Elkahlout ${ }^{1}$, Fayez A. Almabhouh'1, Walid F. Mohamed2, \\ Norman A. Khalaf ${ }^{3}$, Mona A. Al-Sadek4, Randa N. Alfarra5', Lamis T. Al-Moqayed1, \\ Ashraf A. Shafei1, Nedal A. Fayyad', Belal S. Adeem ${ }^{6}$, Ayman W. Dardona ${ }^{7}$, Abdallah S. Awad, \\ Mohammed R. Al-Agha9, Mohammed A. Abd Rabou'9,10
}

\begin{abstract}
${ }^{1}$ Department of Biology and Biotechnology, Faculty of Science, Islamic University of Gaza, Gaza, Palestine
${ }^{2}$ Department of Biological and Geological Sciences, Faculty of Education, Ain Shams University, Roxy, Cairo, Egypt

${ }^{3}$ Department of Environmental Research and Media, National Research Center, Palestine

${ }^{4}$ Accreditation and Quality Commission, Ministry of Education and Higher Education, Gaza, Palestine

${ }^{5}$ Department of Curricula and Teaching Methods, Islamic University of Gaza, Gaza, Palestine

${ }^{6}$ Ministry of Education and Higher Education, Gaza, Palestine

${ }^{7}$ Environment Quality Authority, Gaza, Palestine

${ }^{8}$ Department of Medical Laboratory Sciences, Faculty of Health Sciences, Islamic University of Gaza, Gaza, Palestine ${ }^{9}$ Department of Environment and Earth Sciences, Faculty of Science, Islamic University of Gaza, Gaza, Palestine

${ }^{10}$ Department of Information Technology, University College of Applied Sciences, Gaza, Palestine

Email: *arabou@iugaza.edu.ps
\end{abstract}

How to cite this paper: Abd Rabou, A.N., Elkahlout, K.E., Almabhouh, F.A., Mohamed, W.F., Khalaf, N.A., Al-Sadek, M.A., Alfarra, R.N., Al-Moqayed, L.T., Shafei, A.A., Fayyad, N.A., Adeem, B.S., Dardona, A.W., Awad, A.S., Al-Agha, M.R. and Abd Rabou, M.A. (2021) Occurrence and Some Ecological Aspects of the Golden Jackal (Canis aureus Linnaeus, 1758) in the Gaza Strip, Palestine. Open Journal of Ecology, 11, 105-125.

https://doi.org/10.4236/oje.2021.112010

Received: January 9, 2021

Accepted: February 6, 2021

Published: February 9, 2021

\begin{abstract}
The Golden Jackal (Canis aureus Linnaeus, 1758), which belongs to the Canidae family, is an opportunist carnivore in the Gaza Strip (365 square kilometers). The current study aims at giving notes on the occurrence and some ecological aspects of the species in the Gaza Strip, Palestine. The study, which lasted 14 years (2007-2020), is descriptive and cumulative in its style. It was based on frequent field visits, direct observations and meetings and discussions with wildlife hunters, farmers and other stakeholders. The findings of the study show that Gazans are familiar with the Golden Jackal to the extent that a Gazan family holds the Arabic name of the animal, which is "Wawi". The Golden Jackal was sometimes encountered and hunted in the eastern parts of the Gaza Strip, which are characterized by the presence of wilderness areas, intensive agriculture, poultry pens and solid waste landfills. Like other a few mammalian faunas, the adult Golden Jackals enter the Gaza Strip through gaps in or burrows beneath the metal borders separating the Gaza Strip from the rest of the Palestinian Territories and Egypt. Gaza zoos were found to harbor tens of Golden Jackals trapped or hunted by clever wildlife hunters using different means such as wire cages known locally as "maltash"
\end{abstract}


Copyright $\odot 2021$ by author(s) and Scientific Research Publishing Inc. This work is licensed under the Creative Commons Attribution International License (CC BY 4.0). http://creativecommons.org/licenses/by/4.0/ (c) (i) Open Access and foothold traps with metal jaws that may cause lesions to the trapped animals. Poisoning and shooting were also common methods used to control the jackals and other carnivores causing harm to agriculture and livestock. The animal was known among the Gazans as an omnivore, feeding on wild and domestic animals in addition to plant materials, garbage and carrions. In conclusion, the study recommends the need to raise ecological awareness to preserve the Golden jackal and to adopt safe control measures for jackals and other carnivores, including the construction of protective fences for agricultural fields and animal pens.

\section{Keywords}

Carnivores, Golden Jackals, Trapping, Foothold Traps, Wildlife Hunters, Zoos, Gaza Strip

\section{Introduction}

Palestine (27,000 square kilometers) is a biodiversity rich country because of its strategic geographic position at the meeting point of Asia, Africa and Europe and the three zoogeographical areas: Palaearctic, Afrotropical, and Oriental. The variation of landscapes, ecosystems, habitats and niches promotes species diversity of plants and animals of different categories [1]. In fact, Palestine is home to more than a dozen carnivore species representing the families of Canidae, Felidae, Mustelidae, Herpestidae and Hyaenidae [1] [2]. The Golden Jackal (Canis aureus Linnaeus, 1758), which belongs to the Canidae family, is one of the commonest carnivores worldwide [3] [4] [5] and in the Middle East countries [6]-[15] including Palestine [1] [16]. It was responsible for losses in both agricultural and livestock production in the region [17] [18] [19] [20]. Although the Golden Jackal is a common breeder in the West Bank which has relatively vast wild areas compared to the Gaza Strip, it seems to be not a breeder carnivore to do so in the Gaza Strip. Sightings and hunting of the Golden Jackal in the Gaza Strip were confirmed by both wildlife hunters and local people as many as tens of the species were caged at Gaza zoos [16].

Work on Golden Jackals seems to be very extensive and intensive worldwide, especially in the Middle East region. A lot of studies dealing with the biology and ecology of Golden Jackal were surveyed [12] [16] [17] [20] [21] [22]-[61]. As far as the Palestinian Territories are concerned, no specific studies targeting Golden Jackals have been surveyed. All that is present in this regard is represented by surveys of vertebrate diversity in the occupied Palestinian Territories (West Bank and Gaza Strip) dealing with the occurrence of mammalian fauna including the carnivores [1] [2] [16] [62] [63] [64]-[77]. Hence, the absence of particular studies promoted the conduction of the current study which comes to give notes on the occurrence and ecology of the Golden Jackal (Canis aureus Linnaeus, 1758) in the Gaza Strip. The importance of the current work comes from 
the fact that it is the first of its kind dealing with one of the largest carnivores occurring in the totally fenced, small area of the Gaza Strip, which represents only $1.5 \%$ of the total area of Palestine.

\section{Materials and Methods}

\subsection{The Gaza Strip}

The Gaza Strip (365 square kilometers) is a coastal zone lying in the southern part of the Palestinian coast along the eastern shore of the Mediterranean basin (Figure 1). It is surrounded by occupied Palestinian Territories from the east and north, Egypt to the south and the Mediterranean to the west. It is composed of five governorates: North Gaza, Gaza, Middle, Khan Younis, and Rafah. The Gaza Strip has a population of about 2.2 million, mostly refugees from the 1948 Nakba. The population density is about 5500 inhabitants per square kilometer, making the Gaza Strip one of the most densely populated areas in the world [78]. The Gaza Strip is characterized by its semi-dry Mediterranean climate, which is hot in summer and cold in winter. The average temperatures in the Gaza Strip range from 25 degrees Celsius in summer to 13 degrees Celsius in winter. The average annual rainfall is $300 \mathrm{~mm}$. The daily relative humidity fluctuates between $65 \%$ and $85 \%$ in summer and between $60 \%$ and $80 \%$ in winter. Sand dunes are the main feature of the western part of the Gaza Strip, while the clay and clayey lands predominate in the eastern part [78].

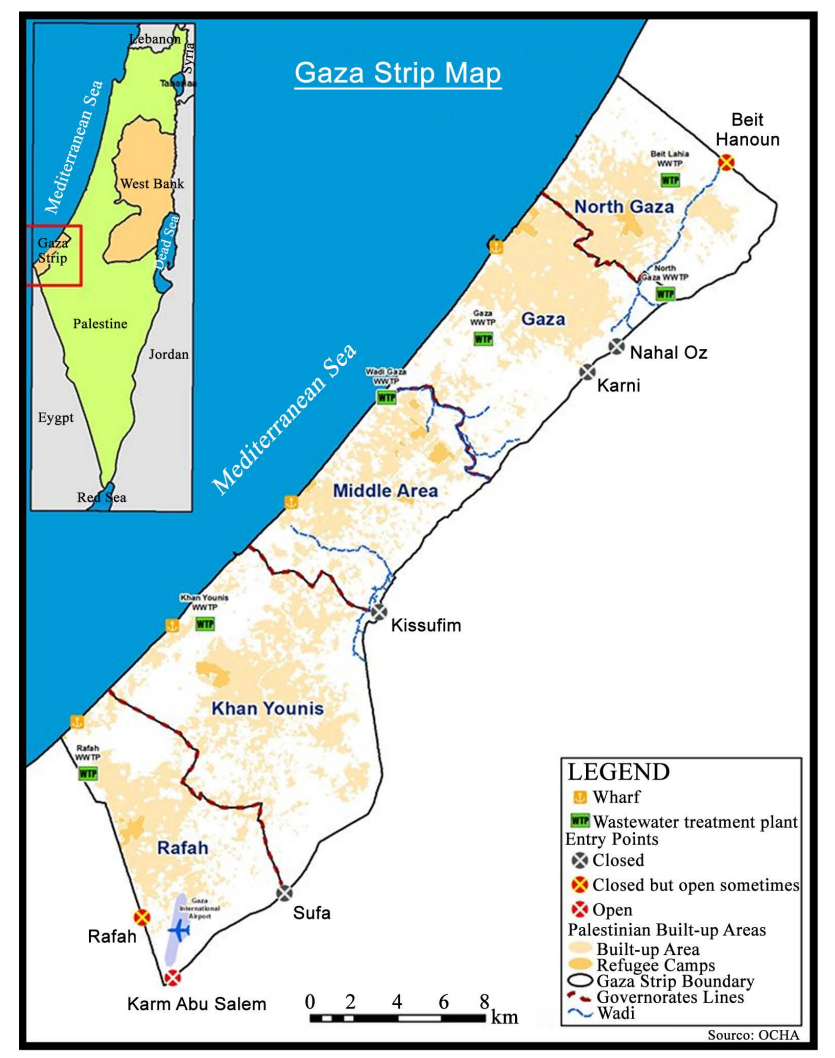

Figure 1. A map showing the position of the Gaza Strip in Palestine. 


\subsection{Procedure}

The current study, which lasted 14 years (2007-2020), is descriptive and cumulative in its style. It was a part of a large study dealing with vertebrate fauna. It was based on frequent visits and direct observations of wildlife, with particular emphasis on Golden Jackals. Many ecosystems within the limits of the Gaza Strip have been surveyed. These ecosystems included the three wadis or valleys of the Gaza Strip (Wadi Gaza, Wadi Beit Hanoun and Wadi Salqa), agricultural orchards, and Al-Mawasi ecosystem and sand dunes lying in the western belt of the Gaza Strip. Particular emphasis was paid to the eastern belt of the Gaza Strip near the political borders with Israel because of its specialty in harboring opportunist mammals that cross the borders through gaps and/or burrows and enter the Gaza Strip such as gazelles, Grey Wolf, Red Fox and the Golden Jackal; the core of the current study. It is worth mentioning that the eastern belt of the Gaza Strip which is characterized by its richness in cereal, vegetable and fruit production, animal husbandries and poultries, and the presence of the three major solid waste landfills. The zoological gardens (zoos), which prevail in the whole governorates of the Gaza Strip, were surveyed for their animal and Golden Jackal contents. Furthermore, the biology exhibitions and animal collections of the local universities were visited and monitored. Meetings and discussions with wildlife hunters, local inhabitants, farmers and owners of poultry pens and zoos were continuously carried out in order to get more info and to close the gaps regarding the occurrence, ecology and risks of the Golden Jackal in the Gaza Strip. Finally, the use of professional binoculars and digital cameras was of an utmost priority throughout the succeeding stages of the current study for documentary and confirmatory purposes.

\section{Results}

\subsection{Description of the Palestinian Golden Jackal}

According to specimens encountered in the field (Figure 2), hunted by some wildlife hunters and caged at Gaza zoos (Figure 3) or found dead on a few occasions in the Palestine environment, the adult Golden Jackal is a medium-sized carnivore belonging to the Canidae family, which includes wolves, dogs and foxes. It has a yellow color mixed with gray; a color that may change depending on the age, season and region. The animal is nocturnal in the sense that it is active at night, especially in areas inhabited by humans, to feed on a different variety of food items. Gazans (the people of the Gaza Strip) are familiar with this carnivore species to the extent that a Gazan family holds the Arabic name of the animal; "Wawi". Gazans said that the animal often tries to rob villages and farms at night to steal chickens and young animals. The Golden Jackal does not howl except at night and spends its day in bushes and burrows or in water when the temperature is very high.

\subsection{Occurrence of the Golden Jackal in the Gaza Strip}

Adult Golden Jackals are seldom seen around villages and in the vicinity of the 

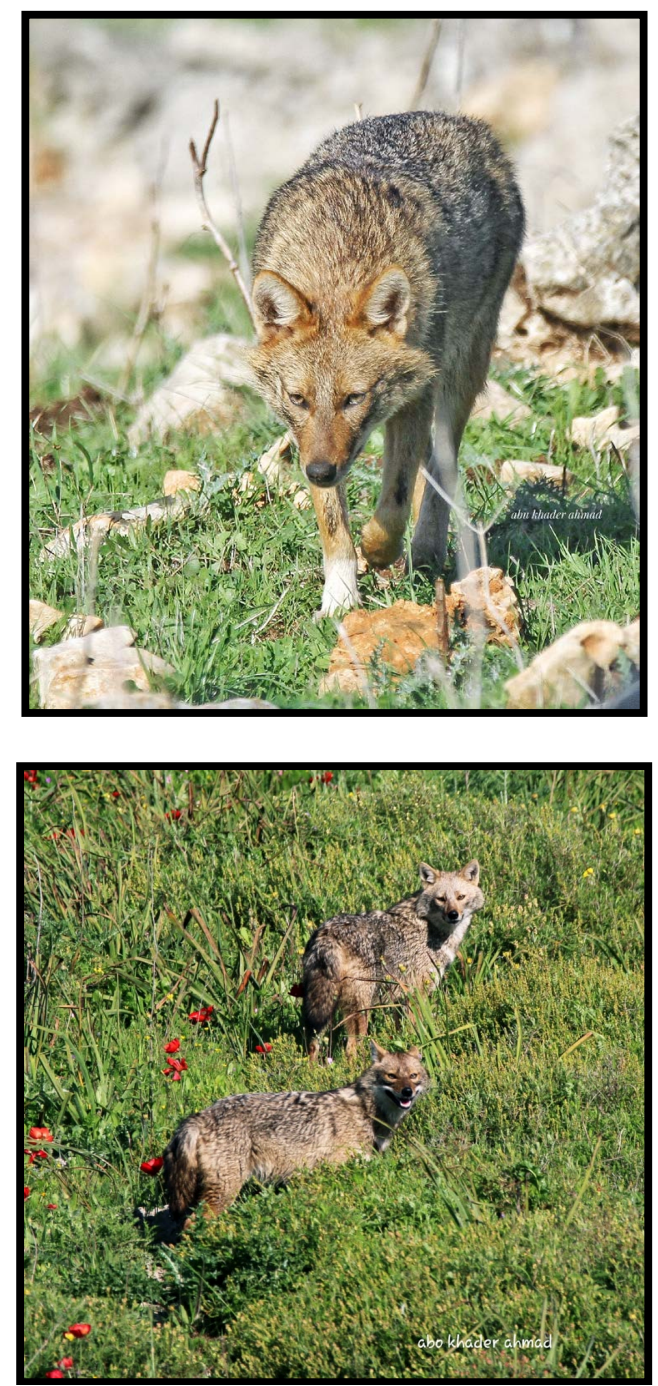

Figure 2. The Golden Jackal (Canis aureus Linnaeus, 1758) is a common carnivore in Palestine [photos taken by Mr. Ahmad K. Jbareen].

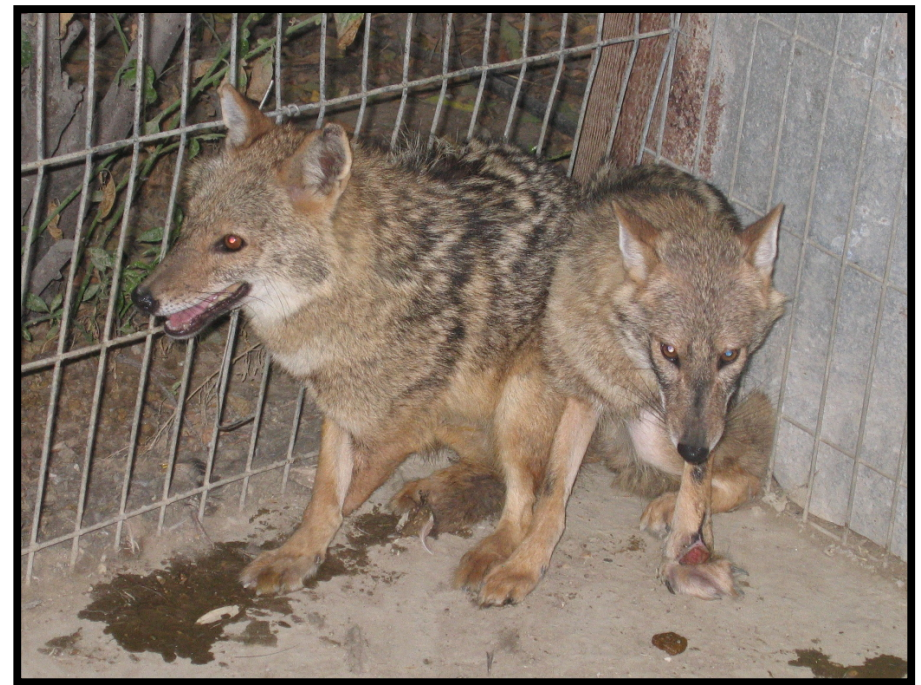

Figure 3. Golden Jackals (Canis aureus) were caged in tens at Gaza zoos. 
three valleys or wadis that cut the Gaza Strip in several directions. Gazans confirmed the presence of adult Golden Jackals in the eastern parts of the Gaza Strip, though the animal was seen and captured in the sandy belt characterizing the western parts of the Gaza Strip. It prefers to live in dry open areas and dry grasslands. Hunting of Golden Jackals along with other mammals; particularly carnivores, artiodactyls and lagomorphs (Table 1), was and is still a common phenomenon in the Gaza Strip. The fate of carnivores captured is killing or selling at cheap prices to the local private zoos prevailing nearly in the whole governorates of the Gaza Strip. Tens of Golden Jackals were encountered by the authors at Gaza zoos throughout the study period (Figure 3). The zoo cages harboring the animal were found to contain from two to five individuals for each.

In fact, all the specimens of Golden Jackals seen, captured or caged at Gaza zoos within the limits of the Gaza Strip were adults. The pups or juveniles of the animal have never been seen or hunted in the Gaza Strip. According to wildlife hunters and farmers, the Golden Jackal is not a breeder animal in the Gaza Strip. Its occurrence in the local environment is restricted to adults because the animal, which prevails in Palestine, comes to the Gaza Strip through earth burrows or gaps found in the politically wired borders isolating the Gaza Strip from the rest of Palestine. In spite of that, breeding of the Golden Jackal was proved by many zoo owners. Unfortunately, none of the pups survived for long due to poor care and parents devour their young. Zoo owners claimed that they have no experience dealing with jackal pups, and at the same time, jackals need vast areas that were not present within zoos, in order to succeed in their breeding biology.

From another point of view, a few carcasses of the Golden Jackal were encountered by the authors and their colleagues throughout the study period. Some of these Jackals were shot by hunting guns, while others were found dead without showing signs of gunfire. Some farmers claimed that many carnivores, including

Table 1. Mammalian fauna captured for different purposes in the Gaza Strip.

\begin{tabular}{|c|c|c|}
\hline Family & Common Name & Scientific Name \\
\hline \multicolumn{3}{|c|}{ Order Carnivora } \\
\hline \multirow{3}{*}{ Canidae } & Golden Jackal & Canis aureus Linnaeus, 1758 \\
\hline & Grey Wolf & Canis lupus Linnaeus, 1758 \\
\hline & Red Fox & Vulpes vulpes Linnaeus, 1758 \\
\hline Herpestidae & Egyptian Mongoose & Herpestes ichneumon Linnaeus, 1758 \\
\hline Mustelidae & Marbled Polecat & Vormela peregusna Güldenstädt, 1770 \\
\hline Felidae & Jungle Cat & Felis chaus Schreber 1777 \\
\hline \multicolumn{3}{|c|}{ Order Artiodactyla } \\
\hline \multirow{2}{*}{ Bovidae } & Palestine Mountain Gazelle & Gazella gazelle Pallas 1766 \\
\hline & Dorcas Gazelle & Gazella dorcas Linnaeus, 1758 \\
\hline \multicolumn{3}{|c|}{ Order Carnivora } \\
\hline Leporidae & Cape Hare & Lepus capensis Linnaeus, 1758 \\
\hline
\end{tabular}


the Golden Jackal, Red Fox (Vulpes vulpes) and Egyptian Mongoose (Herpestes ichneumon), that attack their domestic animals, crops and property, were commonly poisoned using various pesticides and poisons because of their pest behavior. On one occasion only, a dead specimen was brought to the Biology Department of the Islamic University in 2007 for the purpose of embalming and preserving it inside the department, but due to the weakness of the capabilities, the specimen was not embalmed and was subsequently discarded. As was claimed by the person who brought the specimen, the Golden Jackal was caught by hand in North Gaza and kept in a special place inside his house. The person did not know how to take care of it until the animal passed away.

\subsection{Feeding Habits of Golden Jackals in the Gaza Strip}

In spite of its classification in the order Carnivora (mammals that have specialized in primarily eating flesh), the Golden Jackal is an omnivore in the sense that it feeds upon both animal and plant materials; particularly fruits. The eastern part of the Gaza Strip is mostly an agricultural territory of cereals, vegetables and fruits (melon, watermelon, citrus, date palm, almonds, peaches, etc.). The animal was known among the Palestinians, and hence the Gazans, in its predation on domestic ungulates, hares and rabbits, rodents, lizards, snakes, frogs, birds, insects and fruits. Moreover, the animal is a scavenger in the sense that it feeds on garbage, carrions and carcasses of sheep and goats and other animals reared in the Gaza Strip.

\subsection{Why Do Some Gazans Combat Golden Jackals?}

Meetings with some farmers living in the eastern parts of the Gaza Strip demonstrated that the damages of the Golden Jackal to farmers were restricted to:

1) The Golden Jackal is an opportunist that attacks poultry farms and pens of domestic animals; stealing and feeding on them.

2) The Golden Jackal is known among all Palestinians for its attacks on farms and agricultural crops such as watermelon, melons, corn and sugarcane. For this reason, Gazan farmers claimed that they resort to tightening the fence of their farms to avoid the attack of the animal.

3) Golden Jackals like many members of the Canidae family; were supposed to play a role in the epidemiology and transmission of rabies to humans, although the main source of rabies in Palestine is stray and feral dogs.

4) Although it did not happen at all in the Gaza Strip, some farmers claimed that some jackals may attack children and kill them. Those farmers told that they have heard some stories occurring in some countries having large populations of Golden Jackals.

5) Some farmers claimed that the killing of Golden Jackals may be carried out by some Gazans because they believed that they might be wolves or stray and mad dogs that might attack them or their property and domestic animals. It is worth noting that some jackals at Gaza zoos have the inscription "wolf" on them 
due to the lack of clear distinction between wolves and jackals and even some races of dogs.

\subsection{Are There Benefits for Jackals in the Gaza Strip?}

In spite of the previously mentioned damages of Golden Jackals on people, livestock and farms, some farmers and local people have argued for the presence of Golden Jackals in the Gaza environment, citing some of their ecological and economic benefits as follows:

1) The Golden Jackal is beneficial to humans in the sense that it is considered one of the cleaners of the environment, because the animal is a scavenger as it feeds on garbage and carcasses of dead animals. As a result, the animal eliminates the health problems that may result from the accumulation of dead animals in streets and farms and plays an important ecological role in the initial decomposition of animal carcasses.

2) The Golden Jackal also benefits farmers by feeding on rodents and other harmful animals including insects that are considered agricultural pests, thus preventing the increase of their populations and reducing the application of dangerous pesticides to combat such pests.

\subsection{Local Methods of Golden Jackal Trapping, Hunting and Control}

Although it has a limited occurrence in the Gaza Strip, many trapping and control strategies have been adopted by Gazans to deal with the attacks of the Golden Jackal on their livestock and properties. These included:

1) The application of wire cage traps of different sizes known locally as "maltash" to catch Golden Jackals and other wild animals. Cage traps are designed to catch live animals in a cage. They are usually baited, sometimes with food bait and sometimes with a live "lure" animal. Cage traps usually have a trigger located in the back of the cage that causes a door to shut. The closure of the trap door prevents the animal from escaping.

2) Foothold or leghold traps with metal jaws, known locally as "fakh", have been used to catch jackals (Figure 4). These traps are commonly used by Gazans to trap Cape or Brown Hares (Lepus capensis) for feeding purposes. This method was experienced to cause harm and painful lesions to both jackals and other non-target species. In 2008, a live specimen of the Red Fox (Vulpes vulpes) missing a limb was found in the zoo of Rafah city, due to being caught by a foothold trap with metal jaws in eastern Gaza Strip (Figure 5).

3) Poisoning or the use of poisons by the application of poisoned baits. Dead lambs, chicken and ducks were stated to be used as poisoned baits by a few Gazan farmers.

4) Shooting using guns was and is still a common tool in the hunting process of wild animals including the relatively larger carnivores entering the Gaza Strip from Israel or living and roaming in it such as mongooses, wolves, foxes and jackals (Figure 6). 


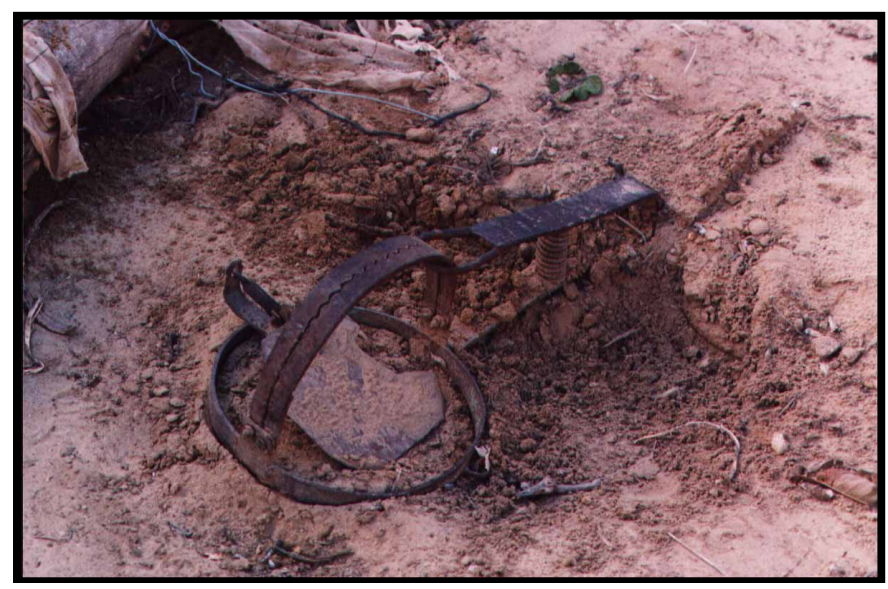

Figure 4. A foothold traps with metal jaws missing some of its parts was encountered in eastern Gaza Strip to catch hares and other wildlife species.

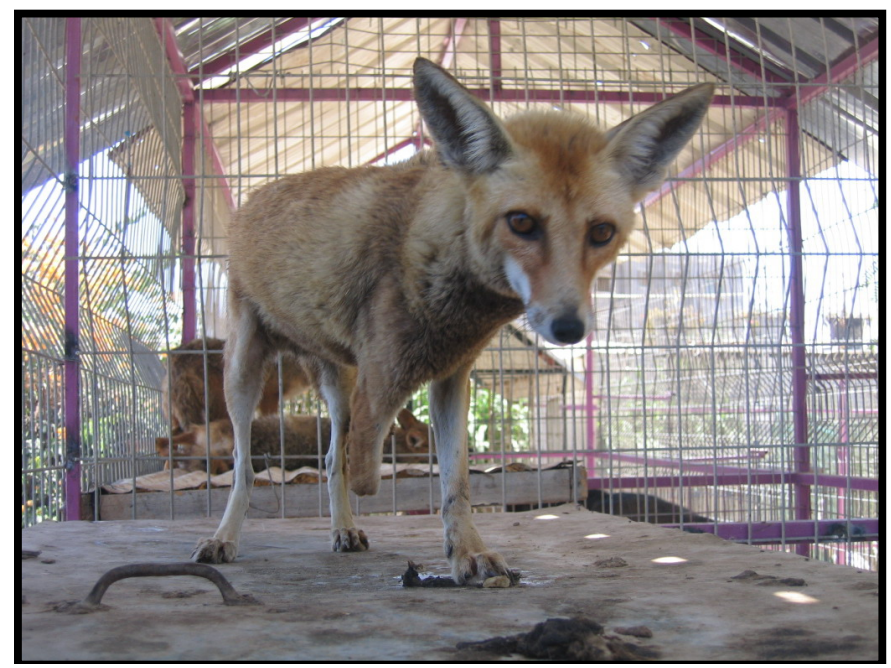

Figure 5. A Red Fox (Vulpes vulpes) missing one of its limbs was encountered at the Rafah zoo in 2008 because of the use of the indiscriminate foothold traps with metal jaws in eastern Gaza Strip.

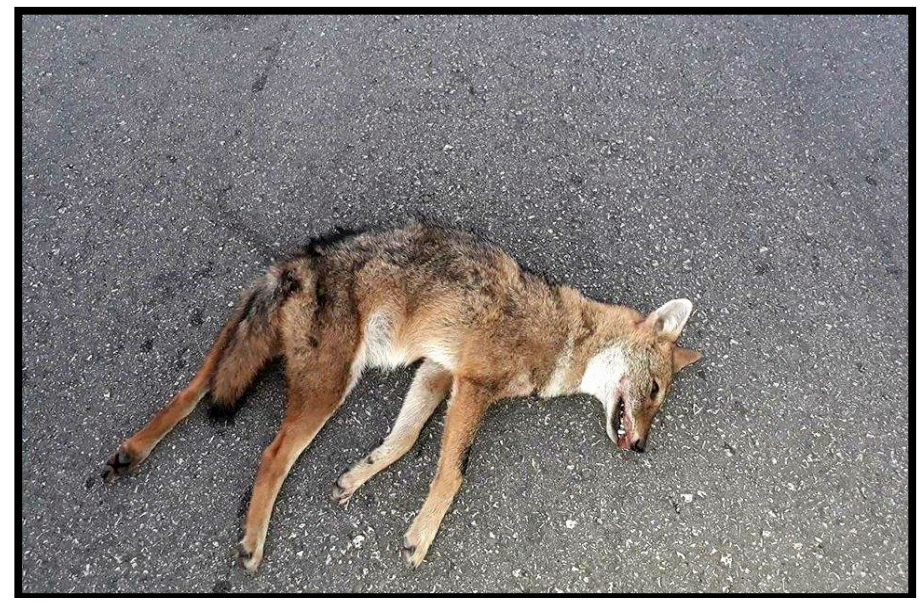

Figure 6. Shooting is a common phenomenon in the Palestinian territories to kill pest carnivores including the Golden Jackal. 
5) Poaching and hand-holding were recorded in rare cases for the catch of the Golden Jackal in the Gaza Strip, as a person pursued a Jackal until it entered a place where he could hold it.

\section{Discussion}

Palestine is home to more than 100 mammalian species, with carnivores constituting a significant part of these mammals [1]. The Gaza Strip, which lies at the southern part of the Palestinian coast along the eastern shore of the Mediterranean basin, is home to eight carnivore species [16], of which the Egyptian Mongoose (Herpestes ichneumon) is the commonest [16] [62] [63] [64] [65] [66]. Limited numbers of the Golden Jackal (Canis aureus) and the Red Fox (Vulpes vulpes) occur nowadays in the various ecosystems of the Gaza Strip. The latter was known to have recent local breeding success (Personal Communications). Prior to 2000, large and medium-sized mammals seemed not to occur in the Gaza Strip because of political borders constructed by the Israeli occupation to isolate the Gaza Strip from the rest of the occupied Palestine. In addition, the Gaza Strip experienced during the occupation era internal borders constructed by the Israeli settlements to completely isolate themselves from the Palestinian cities and refugee camps for security reasons. All these borders within and around the Gaza Strip contributed much to the prevention of ecological flow of large and medium-sized mammals between the Palestinian land masses represented here by the West Bank, Gaza Strip and the other occupied Palestinian lands currently known as Israel [65]. In the same context, the construction of the cement Israeli Apartheid and Segregation Wall in the West Bank since the beginning of 2000s had disastrous impacts on wildlife ecology and biodiversity flow as pointed out by Abdallah and Swaileh [79].

It was well known that Golden Jackals were present in the Gaza Strip 6 - 7 decades ago, but due to the presence of the separation fence and barbed wire, agricultural development, space constraints, population increase, and the lack of natural spaces, they have declined. Their numbers have reached zero. After the witnessed Israeli withdrawal from the Gaza Strip in 2005, and the dismantling of the internal borders of the Israeli settlements, the Gaza Strip witnessed from time to time limited influxes of some wild mammals such as gazelles and carnivores, including the Golden Jackal; the main focus of the current study. Immediately after the Israeli withdrawal, the Gaza Strip witnessed a boom in the opening of many private zoos in all its governorates. Such zoos encouraged the hunting and trapping of wildlife [16] [63] [64] [80]; especially wild mammals, to be sold later to these zoos. The Golden Jackal was and is still considered one of the largest carnivore mammals, which was encountered in dozens in the zoos of the Gaza Strip [16]. Such a presence in relatively big numbers inside zoos made the single zoo cage to harbor from two to five individuals of the animal as the findings of the current study pointed out.

Most hunting and trapping activities of wildlife took place in the eastern parts of the Gaza Strip. This, of course, could be attributed to many logic reasons. 
1) Large and medium-sized mammals including the Golden Jackal enter the Gaza Strip through gaps in the political fence separating the Gaza Strip from both Israel and Egypt. Underground burrows constitute another way for carnivore entrance to the Gaza Strip.

2) The concentration of most poultries and animal husbandries in the eastern part of the Gaza Strip attracts such carnivore flow. This may interpret the tendency of local inhabitants and farmers to kill and poison such carnivore species threatening their livestock. Abd Rabou [66] pointed out the killing and poisoning of the Egyptian Mongoose by Gazans because of its attack on poultries. In Libya, Bsissa et al. [81] ensured the occurrence of the Golden Jackal in and around villages rich in domestic animal pens.

3) The eastern belt of the Gaza Strip does not enjoy a crowded population, but it is very rich in agricultural fields and wilderness areas, which attract a large variety of mammals, birds and reptiles, which in turn constitute a source of food for predators and mammalian carnivores, including jackals [16] [66].

4) The solid waste landfills, which prevail in the eastern belt of the Gaza Strip, may play a role in attracting some animals such as Red Foxes, Golden Jackals and Grey Wolves because these landfills are very attractive to a variety of wildlife species such as birds, reptiles and small mammals, which in turn constitute good food items to such carnivores.

5) The nocturnal behavior of most carnivores facilitates their predation on both wild and domestic animals and even fruits at times the eastern regions of the Gaza Strip are enjoying complete calm due to the departure of farmers to their relatively remote homes, and because of the military and security measures and risks imposed by Israel in the border areas. These areas were subject to Israeli military incursions and shootings especially during wars and instability times. It should be noted here that a number of wildlife hunters have been killed while practicing their hobbies in these relatively pristine areas [62].

6) It is well known that large mammals have bigger home ranges. Hence, the entrance of foxes, wolves, jackals and even gazelles into the Gaza Strip could be attributed to the bigger home ranges they have [82] [83] compared to smaller mammals, which usually have smaller home ranges [84]. In the Negev Desert, which is proximate to the Gaza Strip, Afik and Alkon [83] estimated a minimum home range of a pair of the Grey Wolf (Canis lupus pallipes) to be $60.3 \mathrm{~km}^{2}$.

The Golden Jackal is an opportunistic omnivore; feeding on both animal and plant materials; particularly fruits. It has a great similarity in food composition with other canids and carnivores [35] [36] [85] [86]. The eastern regions of the Gaza Strip are full of agricultural fields with a variety of crops, including watermelon, melon, corn, wheat, onion, barley, potato, carrot and many other vegetables and fruits. The entry of Golden Jackals and other wild animals across the nearby borders causes agricultural problems for farmers as they feed on agricultural crops and destroy them. Such attacks often force farmers to adopt various means to combat and control these animals. According to Mendelssohn [17], Franck and Farid [86] and Amr et al. [87], the consumption of leaves, vegetables 
and fruits and other fibrous plant tissues is widespread among carnivores; with the Golden Jackal is just an example. In Israel, Mendelssohn [17] reported Golden Jackals as a menace to agriculture and the associated complications of control efforts. In Bangladesh, the Golden Jackal was known to attack agricultural crops and feed upon sugarcane, corn, melon and vegetables. Many of the jackals were trapped in sugarcane fields. The sugar content of the sugarcane attracts jackals that bite some joints of the stalk of the plant and chew them [88]. Plant materials such as leaves of grass species, barley and vegetables mainly carrot were also identified in feces of Golden Jackals in Ethiopia [61].

The Golden Jackal was and is still known among the Palestinians for its predation on a variety of wildlife species such as hares, rodents, lizards, snakes, frogs, birds and insects, thus controlling their population. The predation of the animal on domestic animals such as sheep, goats, lambs, turkey, geese, ducks, hens, pigeons and many others, form a challenge for Gazans on the ways they should adopt to lower the damage caused by jackals to livestock and domestic life. A lot of studies dealt with analyzing the food contents of the Golden Jackal showed proximate results. In Israel, evidence for food consumption by jackals was primarily derived from studies on scats or gastrointestinal tracts. The main food category of jackals was ungulates, $80 \%$ of which were domestic animals. Other common food types included fruit, birds, small mammals, invertebrates and garbage [53]. According to Yom-Tov et al. [32], 1.5\% - 1.9\% of calves born in the Golan Heights, northern Israel, die due to predation, mainly by Golden Jackals. The high predation rate was attributed to the artificially large jackal population, which was caused by the food provided by humans at illegal landfills. In Israel, one of the important conservation problems caused by increased jackal density is the decreasing density of the northern subspecies of Mountain Gazelle (Gazella gazella gazella) as pointed out by Dolev and Perevolotsky [89]. In Greece, stray dogs and jackals are the only animals that could prey on small, hoofed livestock in areas where there are no wolves [45]. According to local people in Nepal, cattle, pheasants, rodents and lagomorphs were commonly preyed upon by Golden Jackals [90]. The Gazans' perception on the role of the Golden Jackal and other carnivores as environmental cleaners was appreciated and documented in different studies worldwide [57] [91] [92].

The Golden Jackal tends not to attack adult people in the Gaza Strip, but it may attack and harm a young child if it had the opportunity as claimed by some Gazans. Such claims were documented in various countries worldwide. In 1979, two young children were attacked and killed by Golden Jackals near the edge of a village in southern Bangladesh [88]. Also, more than likely the animal plays an important role in the epidemiology of rabies, although the main source of rabies is feral dogs [17] [32] [88] [93] [94]. In fact, rabies is a viral disease that occurs in more than 150 countries and territories worldwide. It was estimated that more than 55,000 people die from rabies every year, mostly in Africa and Asia [95]. From an economic point of view, jackals have been hunted sometimes in some countries to obtain their fur or meat, and they may be raised in homes such as 
domesticated dogs for the purpose of protection. Such practices have never been found in the Palestinian Territories. In Israel, a great number of wildlife species, including carnivores, was known to be poached for meat purposes by guest Thai workers who were introduced to Israel from Thailand as pointed out by Yom-Tov [96].

The use of poisons, toxins and pesticides to control jackals and other vertebrates as well as invertebrate pests in the Gaza Strip carries negative impacts. The use of poisoned baits was stated by many farmers against jackals, though the phenomenon was not very common. In Israel, the attempts to control jackal populations achieved moderate success by application of poisoned baits, mainly strychnine. The use of strychnine resulted in the decrease of the numbers of Griffon Vultures (Gyps fulvus) as well [17]. These poison baits were extremely disastrous as many non-target species such as Egyptian Mongooses, Wild Cats, and Red Foxes were poisoned and negatively impacted. The population of the Palestine Viper (Daboia palaestinae) was said to increase considerably after the conduction of jackal extermination campaign [17]. This was probably connected with the concomitant disappearance of the Egyptian Mongoose (Herpestes ichneumon), which preyed to a large extent on reptiles, including vipers [66]. The situation of poisoning method applied on jackals and other carnivores is not clearly understood in the Gaza Strip. Some Gazans used dead animals like lambs, turkey, chickens and ducks or geese as poisoned baits as the findings showed. As an approach to control Golden Jackals in Israel, Yom-Tov et al. [32] suggested that poisoning should be applied during evening times in carcasses recently predated by jackals, and the remnant poisoned carcasses should be removed in early morning in order to prevent its consumption by vultures and other carrion-feeding animals. In Greece, declines of jackals were partly attributed to the fact that all wild canid species (namely jackals, foxes and wolves) were considered pests during the 1970s and 1980s, and consequently legally persecuted by every possible means, including poisoning [45].

Snaring seems to be of little or no use in the Gaza Strip. Snares, which are described as the silent killers of the forest, are one of the simplest but most effective hunting techniques practiced in the tropics and home-made wire or cable snares are the predominant form of hunting across large areas of Southeast Asia [97]. Instead, shooting by guns was and is still used in the Gaza Strip, with the birds and mammals were the most common victims of shooting [16] [65] [66] [98]. More recently, a Red Fox was shot by wildlife hunters in the Gaza Strip and the photos were posted in the Facebook (Personal Observations). Denning jackal pups could be removed from dens in order to reduce predation on livestock, because the food requirements of adult jackals are less when they do not have pups to tend to [99]. This approach is sometimes applied in countries having great densities of jackals. In the case of the Gaza Strip, there are no signs of jackal breeding, and as such, this method is losing its local significance.

Hunting and trapping of wildlife species is a common phenomenon in the Gaza Strip. Poverty, unemployment, low socioeconomic standards and the Israe- 
li blockade imposed on about 2.2 million people living in the Gaza Strip are strong factors enhancing wildlife hunting for different purposes including meat, rearing at homes, fun, game and trade [16] [62] [63] [64] [67] [68] [69] [80] [98] [100] [101] [102] [103]. The use of live traps such as wire cages and foothold traps was documented in the Gaza Strip. The kind of foothold traps applied in the Gaza Strip is disastrous to wildlife because they are made of pure iron. Such metal foothold traps were known to cause harmful and painful lesions to the mammalian species hunted. Many wild carnivores including jackals, wolves, foxes, hares and even hedgehogs were actual victims. Domestic Cats (Felis catus) and Domestic Dogs (Canis familiaris) were not far away from this tragedy. As shown in Figure 5, a caged Red Fox in Rafah zoo was found missing one of its limbs as a result of the use of the indiscriminate foothold traps with metal jaws. In the USA, standard foothold traps equipped with rubber padded jaws were commonly used as a depredation management tool to control Coyote (Canis latrans) populations [104]. In fact, leghold traps, which have been banned in some countries of the world, pose a threat to the health and life of hunted animals. These traps break and crush the animal's limb, immobilize the animal and make it vulnerable to predation and without shelter from the harsh weather conditions. Hunting these animals prevents them from returning to their dens, and therefore their young are left alone with no food and care, so they die.

\section{Conclusion}

In conclusion, the Golden Jackal, in spite of its limited occurrence, represents a large carnivore species that plays an important ecological role in the Gaza Strip. In the light of this fact, the current study recommends the need to raise ecological awareness among Gazans to protect the Golden jackal and to adopt safe control measures for jackals and other carnivores, including the construction of protective fences for agricultural fields and animal pens.

\section{Acknowledgements}

My thanks are due to Mr. Ahmad K. Jbareen, Mr. Bashar S. Jarayseh, Mr. Daoud I. Al-Hali and Mr. Khaled A. Hamode for their continuous help throughout the succeeding stages of this modest study.

\section{Conflicts of Interest}

The authors declare no conflicts of interest regarding the publication of this paper.

\section{References}

[1] Qumsiyeh, M.B. (1996) Mammals of the Holy Land. Texas Tech University Press, Lubbock, 389 p.

[2] Albaba, I. (2016) The Terrestrial Mammals of Palestine: A Preliminary Checklist. International Journal of Fauna and Biological Studies, 3, 28-35. 
[3] Boitani, L. and Bartoli, S. (1983) Simon and Schuster's Guide to Mammals. Simon and Schuster Inc., New York, 511 p.

[4] Merz, G. (1984) Field Guide to Footprints of Larger Mammals of East Africa and Southern Sudan. The Wildlife Unit, College of Natural Resources and Environmental Studies, University of Juba, Juba, 219 p.

[5] Haltenorth, T. and Diller, H. (1996) Mammals of Africa including Madagascar. Harper Collins, London, 403 p.

[6] Harrison, D.L. and Bates, P.J.J. (1991) The Mammals of Arabia. Harrison Zoological Museum, Kent, 354 p.

[7] Shalmon, B., Kofyan, T. and Hadad, E. (1993) A Field Guide to Land Mammals of Israel. Keter, Jerusalem.

[8] Al-Jumaily, M.M. (1998) Review of the Mammals of the Republic of Yemen. Fauna of Saudi Arabia, 17, 477-502.

[9] Mendelssohn, H. and Yom-Tov, Y. (1999) Mammalia of Israel. Israel Academy of Sciences and Humanities, Jerusalem.

[10] Bunaian, F., Hatough, A., Ababaneh, D., Mashaqbeh, S., Yuosef, M. and Amr, Z.S. (2002) The Carnivores of the Northeastern Badia, Jordan. Turkish Journal of Zoology, 25, 19-25.

[11] Hoath, R. (2003) A Field Guide to the Mammals of Egypt. The American University in Cairo Press, Cairo, $234 \mathrm{p}$.

[12] Amr, Z.S. (2012) Mammals of Jordan. 2nd Edition, Al Rai Press, Amman, 308 p.

[13] Essghaier, M.F., Taboni, I.M. and Etayeb, K.S. (2015) The Diversity of Wild Animals at Fezzan Province, Libya. Biodiversity Journal, 6, 245-252.

[14] Urios, V., Donat-Torres, M.P., Ramirez, C., Monroy-Vilchis, O. and Rgribi-Idrissi, H. (2015) The Analysis of the Canid Mitochondrial Genome Studied in Morocco Shows That It Is neither Wolf (Canis lupus) nor Eurasian Jackal (Canis aureus). PeerJ, 4, e1763v1.

[15] Meiri, S., Belmaker, A., Berkowic, D., Kazes, K., Maza, E., Bar-Oz, G. and Dor, R. (2019) A Checklist of Israeli Land Vertebrates. Israel Journal of Ecology and Evolution, 65, 43-70. https://doi.org/10.1163/22244662-20191047

[16] Abd Rabou, A.N. (2009) On the Occurrence of Some Carnivores in the Gaza Strip, Palestine (Mammalia: Carnivora). Zoology in the Middle East, 46, 109-112. https://doi.org/10.1080/09397140.2009.10638336

[17] Mendelssohn, H. (1972) Ecological Effects of Chemical Control of Rodents and Jackals in Israel. In: Favar, T.M. and Milton, J.P., Eds., The Careless Technology. Ecology and International Development, Natural History, New York, 527-544.

[18] Moran, S. and Keidar, H. (1993) Checklist of Vertebrate Damage to Agriculture in Israel. Crop Protection, 12, 173-182. https://doi.org/10.1016/0261-2194(93)90105-R

[19] Moran, S. (1981) Damage by Vertebrates to Plastic Irrigation Pipes in Israel. Phytoparasitica, 9, 211-216. https://doi.org/10.1007/BF03158581

[20] Nemtzov, S.C. and King, R. (2001) Management of Wild Canids (Fox, Jackal and Wolf) in Israel, with Respect to Their Damage to Agriculture and to the Spread of Rabies. In: Pelz, H.J., Cowan, D.P. and Feare, C.J., Eds., Advances in Vertebrate Pest Management II, Filander Verlag, Furth, 219-230.

[21] Macdonald, D.W. (1979) The Flexible Social System of the Golden Jackal (Canis aureus). Behavioral Ecology and Sociobiology, 5, 17-38.

https://doi.org/10.1007/BF00302692 
[22] Ferguson, W.W. (1981) The Systematic Position of Canis aureus lupaster (Carnivora, Canidae) and the Occurrence of Canis lupus in North Africa, Egypt and Sinai. Mammalia, 45, 459-465. https://doi.org/10.1515/mamm.1981.45.4.459

[23] Gasperetti, J., Harrison, D.L. and Büttiker, W. (1985) The Carnivora of Arabia. Fauna of Saudi Arabia, 7, 397-461.

[24] Amr, Z.S., Woodburry, S. and Disi, A.M. (1987) On a Collection of Mammals from Jordan. Dirasat, 14, 131-136.

[25] Amr, Z.S., Kalishaw, G., Yosef, M., Chilcot, B.J. and Al-Budari, A. (1996) Carnivores of Dana Nature Reserve (Carnivora: Canidae, Hyaenidae and Felidae), Jordan. Zoology in the Middle East, 13, 5-16. https://doi.org/10.1080/09397140.1996.10637701

[26] Amr, Z.S. and Disi, A. (1988) Jordanian Mammals Acquired by the Jordan University Natural History Museum. Publication of the University of Jordan, Amman, 32 p.

[27] Amr, Z.S. (2000) Jordan Country Study on Biological Diversity: Mammals of Jordan. United Nations Environment Program (UNEP), Amman, 100 p.

[28] Aloufi, A.A. and Amr, Z.S. (2018) Carnivores of the Tabuk Province, Saudi Arabia (Carnivora: Canidae, Felidae, Hyaenidae, Mustelidae). Lynx, n.s. (Praha), 49, 77-90. https://doi.org/10.2478/lynx-2018-0010

[29] Frankenberg, E. (1991) Jackal (Canis aureus) Census in the Judean Lowland. Israel Journal of Zoology, 37, 173.

[30] Dayan, T., Simberloff, D., Tchernov, E. and Yom-Tov, Y. (1992) Canine Carnassials: Character Displacement in the Wolves, Jackals and Foxes of Israel. Biological Journal of the Linnean Society, 45, 315-331. https://doi.org/10.1111/j.1095-8312.1992.tb00647.x

[31] Qumsiyeh, M.B., Amr, Z.S. and Shafei, D. (1993) The Status and Conservation of Carnivores in Jordan. Mammalia, 57, 55-62.

https://doi.org/10.1515/mamm.1993.57.1.55

[32] Yom-Tov, Y., Ashkenazi, S. and Viner, O. (1995) Cattle Predation by the Golden Jackal Canis aureus in the Golan Heights, Israel. Biological Conservation, 73, 19-22. https://doi.org/10.1016/0006-3207(95)90051-9

[33] Yom-Tov, Y. and Yom-Tov, S. (2012) Observations on Variation in Skull Size of Three Mammals in Israel during the 20th Century. Zoologischer Anzeiger, 251, 331-334. https://doi.org/10.1016/j.jcz.2011.12.003

[34] Linhart, S.B., King, R., Zamir, S., Naveh, U., Davidson, M. and Perl, S. (1997) Oral Rabies Vaccination of Red Foxes and Golden Jackals in Israel: Preliminary Bait Test Evaluation. OIE Scientific and Technical Review, 16, 874-880. https://doi.org/10.20506/rst.16.3.1076

[35] Basuony, M.I. (1998) Feeding Ecology of Mammalian Assemblages of Sinai, Egypt. Proceedings of the Egyptian Academy of Sciences, 48, 271-286.

[36] Basuony, M.I., Saleh, M., Riad, A. and Mohamed, W.F. (2005) Food Composition and Feeding Ecology of the Red Fox Vulpes vulpes (Linnaeus, 1758) in Egypt. Egyptian Journal of Biology, 7, 96-102.

[37] Basuony, M.I., Mohamed, W.F. and Shalabi, M.A. (2013) Food and Feeding Ecology of the Egyptian Mongoose, Herpestes ichneumon (Linnaeus, 1758) in Egypt. Journal of Applied Sciences Research, 9, 5811-5816.

[38] Saleh, M. and Basuony, M. (2014) Mammals of the Genus Canis Linnaeus, 1758 (Canidae; Carnivore) in Egypt. Egyptian Journal of Zoology, 62, 49-92. 
https://doi.org/10.12816/0009337

[39] Mohamed, W.F. and Basuony, M.I. (2016) Food Composition and Feeding Ecology of the Arabian Red Fox Vulpes vulpes arabica (Thomas, 1902) in Sakaka, Northern Saudi Arabia. Journal of Bioscience and Applied Research, 2, 723-728. https://doi.org/10.21608/jbaar.2016.109503

[40] Mohamed, W.F. (2011) Genus Vulpes in Egypt: The Evolution and the Phylogenetic History. LAP Lambert Academic Publishing, Düsseldorf, 177 p.

[41] Mohamed, W.F. (2016) On the Occurrence of Arabian Red Fox Vulpes vulpes arabica (Thomas, 1902) in Sakaka, Northern Saudi Arabia. Pakistan Journal of Zoology, 48, 1979-1982.

[42] Mohamed, W.F. (2017) New Recorded Specimens of the North African Jackal (Canis aureus lupaster, Schwarz, 1926), Canidae, from Libya. Indian Journal of Natural Sciences, 7, 12385-12394.

[43] Özkurt, Ş.Ö., Sözen, M., Yiğit, N. and Çolak, E. (1998) Notes on Distributional Records and Some Characteristics of Five Carnivore Species (Mammalia: Carnivora) in Turkey. Turkish Journal of Zoology, 22, 285-288.

[44] Can, O.E. (2004) Status, Conservation and Management of Large Carnivores in Turkey. Convention on the Natural Conservation of European Wildlife and Natural Habitats, 24th Meeting, Strasbourg, 29 November-3 December 2004, 1-28.

[45] Giannatos, G., Marinos, Y., Maragou, P. and Catsadorakis, G. (2005) The Status of the Golden Jackal (Canis aureus L.) in Greece. Belgian Journal of Zoology, 135, 145-149.

[46] Abi-Said, M. and Marrouch, A.D. (2007) Distribution of Striped Hyaena (Hyaena hyaena syriaca Matius, 1882) (Carnivora: Hyaenidae) in Urban and Rural Areas of Lebanon. Zoology of the Middle East, 42, 3-14. https://doi.org/10.1080/09397140.2007.10638241

[47] Jaeger, M.M., Haque, E., Sultana, P. and Bruggers, R.L. (2007) Daytime Cover, Diet and Space-Use of Golden Jackals (Canis aureus) in Agro-Ecosystems of Bangladesh. Mammalia, 71, 1-10. https://doi.org/10.1515/MAMM.2007.016

[48] Steinman, A., Millet, N., Frenkel, C., King, R. and Shpigel, N.Y. (2007) Presence of Antibotulinum Neurotoxin Antibodies in Selected Wild Canids in Israel. Journal of Wildlife Diseases, 43, 548-550. https://doi.org/10.7589/0090-3558-43.3.548

[49] Kamler, J.F., Jacobsen, N.F. and Macdonald, D.W. (2008) Efficiency and Safety of Soft Catch Traps for Capturing Black-Backed Jackals and Excluding Non-Target Species. South African Journal of Wildlife Research, 38, 113-116. https://doi.org/10.3957/0379-4369-38.2.113

[50] Akhtar, N. and Chauhan, N.P.S. (2009) Food Habits and Human-Jackal Interaction in Marwahi Forest Division, Bilaspur Chhattisgarh. The Indian Forester, 10, 1347-1356.

[51] De Marinis, A. and Masseti, M. (2009) Mammalian Fauna of the Termessos National Park, Turkey. ZooKeys, 31, 221-228. https://doi.org/10.3897/zookeys.31.171

[52] Talmi-Frank, D., Kedem-Vaanunu, N., King, R., Bar-Gal, G.K., Edery, N., Jaffe, C.L. and Baneth, G. (2010) Leishmania tropica Infection in Golden Jackals and Red Foxes, Israel. Emerging Infectious Diseases, 16, 1973-1975. https://doi.org/10.3201/eid1612.100953

[53] Borkowski, J., Zalewski, A. and Manor, R. (2011) Diet Composition of Golden Jackals in Israel. Annales Zoologici Fennici, 48, 108-118.

https://doi.org/10.5735/086.048.0203 
[54] Nader, M.R., El-Indary, S., Abi Salloum, B. and Abou Dagher, M. (2011) Combining Non-Invasive Methods for the Rapid Assessment of Mammalian Richness in a Transect Quadrat Survey Scheme-Case Study of the Horsh Ehden Nature Reserve, North Lebanon. ZooKeys, 119, 63-71. https://doi.org/10.3897/zookeys.119.1040

[55] Cohen, T.M., King, R., Dolev, A., Boldo, A., Lichter-Peled, A. and Bar-Gal, G.K. (2013) Genetic Characterization of Populations of the Golden Jackal and the Red Fox in Israel. Conservation Genetics, 14, 55-63.

https://doi.org/10.1007/s10592-012-0423-1

[56] Rutkowski, R., Krofel, M., Giannatos, G., Ćirović, D., Männil, P., Volokh, A.M., Lanszki, J., Heltai, M., Szabó, L., Banea, O., Yavruyan, E., Hayrapetyan, V., Kopaliani, N., Miliou, A., Tryfonopoulos, G.A., Lymberakis, P., Penezić, A., Pakeltytė, G., Suchecka, E. and Bogdanowicz, W. (2015) A European Concern: Genetic Structure and Expansion of Golden Jackals (Canis aureus) in Europe and the Caucasus. PLoS $O N E, 10$, e0141236. https://doi.org/10.1371/journal.pone.0141236

[57] Ćirović, D., Penezić, A. and Krofe, M. (2016) Jackals as Cleaners: Ecosystem Services Provided by a Mesocarnivore in Human-Dominated Landscapes. Biological Conservation, 199, 51-55. https://doi.org/10.1016/j.biocon.2016.04.027

[58] Gherman, C.M. and Mihalca, A.D. (2017) A Synoptic Overview of Golden Jackal Parasites Reveals High Diversity of Species. Parasites Vectors, 10, 419. https://doi.org/10.1186/s13071-017-2329-8

[59] Elkahwage, I.E. and Jdeidi, T.B. (2018) Survey of the Wild Mammalian Species in Misallatah Nature Reserve and National Park (MNRNP). Attie Memorie DelP ente Fauna Siciliana, 12, 101-112.

[60] Yusefi, G.H., Faizolahi, K., Darvish, J., Safi, K. and Brito, J.C. (2019) The Species Diversity, Distribution, and Conservation Status of the Terrestrial Mammals of Iran. Journal of Mammalogy, 100, 55-71. https://doi.org/10.1093/jmammal/gyz002

[61] Gashe, T. and Yihune, M. (2020) Population Status, Foraging Ecology and Activity Pattern of Golden Jackal (Canis aureus) in Guangua Ellala Forest, Awi Zone, North West Ethiopia. PLoS ONE, 15, e0233556. https://doi.org/10.1371/journal.pone.0233556

[62] Abd Rabou, A.N. (2005) An Ecological Survey and Assessment of Wadi Gaza Nature Reserve, Gaza Strip-Palestine, with Particular Emphasis on Wildlife. PhD Thesis, Department of Environmental Studies, Faculty of Science and Technology, School of Life Sciences, Al-Neelain University, Khartoum, 278 p.

[63] Abd Rabou, A.N. (2011) On the Ecology of Wadi Gaza, Gaza Strip: Survey and Assessment (Wildlife Is Focused). LAP Lambert Academic Publishing, Düsseldorf, 304 p.

[64] Abd Rabou, A.N. (2011) The Palestinian Mammalian Fauna Acquired by the Zoological Gardens in the Gaza Strip. Nusantara Bioscience, 3, 92-101. https://doi.org/10.13057/nusbiosci/n030205

[65] Abd Rabou, A.N. (2019) The Mammalian, Reptilian and Amphibian Fauna of Al-Mawasi Ecosystem, South-Western Gaza Strip-Palestine. Agricultural Research \& Technology: Open Access Journal, 23, 301-314.

[66] Abd Rabou, A.N. (2019) On the Occurrence, Ecology and Risks of the Egyptian Mongoose (Herpestes ichneumon Linnaeus, 1758) in the Gaza Strip-Palestine. Agricultural Research \& Technology: Open Access Journal, 23, 267-276.

[67] Abd Rabou, A.N. (2020) The Palestinian Marine and Terrestrial Vertebrate Fauna Preserved at the Biology Exhibition, Islamic University of Gaza, Bombarded by the Israeli Army in December, 2008. Israa University Journal of Applied Science 
(IUGAS), 4, 9-51.

[68] Abd Rabou, A.N. (2020) On the Owls (Order Strigiformes) Inhabiting the Gaza Strip-Palestine: Mini Review. JOJ Wildlife \& Biodiversity, 3, JOJWB.MS.ID.555603.

[69] Abd Rabou, A.N., Yassin, M.M., Al-Agha, M.R., Hamad, D.M. and Ali, A.S. (2007) Wild Mammals in the Gaza Strip, with Particular Reference to Wadi Gaza. The Islamic University Journal (Series of Natural Studies and Engineering), 15, 87-109.

[70] Yassin, M.M., Abd Rabou, A.N. and Al-Agha, M.R. (2006) Preliminary Survey of Terrestrial Vertebrate Fauna and People's Awareness towards Wildlife in the Northern Governorate of the Gaza Strip. Al-Azhar Bulletin of Science: Zoology \& Botany, 17, 17-41. https://doi.org/10.21608/absb.2006.14718

[71] MedWetCoast (2002) Management Plan: Wadi Gaza. Project for the Conservation of Wetland and Coastal Ecosystems in the Mediterranean Region-MedWetCoast, $171 \mathrm{p}$.

[72] Qumsiyeh, M.B. (2016) Fauna of Wadi Al-Quff Protected Area: Amphibians, Reptiles and Mammals. Jordan Journal of Natural History, 3, 70-79.

[73] Qumsiyeh, M.B., Khalilieh, A., Albaradeiyab, I.M. and Al-Shaikh, B. (2016) Biodiversity Conservation of Wadi Al-Quff Protected Area (Central Palestine) Challenges and Opportunities. Jordan Journal of Natural History (JJNH), 3, 6-24.

[74] Handal, E.N., Qumsiyeh, G.H., Hammash, S.Y. and Qumsiyeh, M.B. (2019) Status and Conservation of the Striped Hyena (Hyaena hyaena) in the Occupied Palestinian Territories (West Bank). Jordan Journal of Natural History (JJNH), 6, 11-18.

[75] Albaba, I. (2017) Surveying Wildlife Roadkills in the West Bank Governorates-Palestine. Journal of Entomology and Zoology Studies, 5, 910-913.

[76] Khalaf-von Jaffa, N.A. (2008) Canis aureus palaestina Khalaf, 2008: A New Golden Jackal Subspecies from the Gaza Strip, Palestine. Gazelle: The Palestinian Biological Bulletin, 80, 1-13.

[77] Khalaf-von Jaffa, N.A. (2008) Carnivora Arabica: Zoological Journey in Palestine, Arabia and Europe between 2005-2008. Self-Publisher: Dr. Norman Ali Khalaf, Sharjah, United Arab Emirates \& Rilchingen-Hanweiler, Deutschland, 396 p.

[78] UNEP (2003) Desk Study on the Environment in the Occupied Palestinian Territories. United Nations Environment Program (UNEP), Nairobi, 188 p.

[79] Abdallah, T. and Swaileh, K. (2011) Effects of the Israeli Segregation Wall on Biodiversity and Environmental Sustainable Development in the West Bank, Palestine. International Journal of Environmental Studies, 68, 543-555. https://doi.org/10.1080/00207233.2011.608504

[80] Abd Rabou, A.N. (2011) Notes on Some Palestinian Bird Fauna Existing in the Zoological Gardens of the Gaza Strip. American-Eurasian Journal of Agricultural \& Environmental Sciences (AEJAES), 11, 159-172.

[81] Bsissa, H.B., Ashour, M.F. and Jdeidi, T.B. (2019) Wild Mammals in Northwestern Libya and the Role of Rain and Temperature in Its Geographical Distribution. The Libyan Journal of Science (An International Journal), 22, 27-44.

[82] Reuven, H. and Geffen, E. (1999) Group Size and Home Range of the Arabian Wolf (Canis lupus) in Southern Israel. Journal of Mammalogy, 80, 611-619. https://doi.org/10.2307/1383305

[83] Afik, D.A. and Alkon, P.U. (2013) Movements of a Radio-Collared Wolf (Canis lupus pallipes) in the Negev Highlands, Israel. Israel Journal of Zoology, 32, 138-146.

[84] Campbell, N.A. (1993) Biology. 3rd Edition, The Benjamin/Cummings Publishing Company, Inc., San Francisco, 1190 p. 
[85] Brahmi, K., Khechekhouche, E., Mostefaoui, O., Doumandji, S., Baziz, B. and Aulagnier, S. (2011) First Quantitative Data on the Diet of the Fennec Fox, Vulpes zerda (Canidae, Carnivora) in Algeria. Folia Zoology, 60, 61-70. https://doi.org/10.25225/fozo.v61.i1.a10.2012

[86] Frank, A.R. and Farid, A. (2020) Many Species of the Carnivora Consume Grass and Other Fibrous Plant Tissues. Belgian Journal of Zoology, 150, 1-70. https://doi.org/10.26496/bjz.2020.73

[87] Amr, Z.S., Abu Baker, M.A. and Rifai, L. (2004) Mammals of Jordan. Denisia, 14, 437-465.

[88] Poche, R.M., Evans, S.J., Sultana, P., Hague, M.E., Sterner, R. and Siddique, M.A. (1987) Notes on the Golden Jackal (Canis aureus) in Bangladesh. Mammalia, 51, 259-270. https://doi.org/10.1515/mamm.1987.51.2.259

[89] Dolev, A. and Perevolotsky, A. (2005) The Red Book: Vertebrates in Israel. Israel Nature and Parks Authority, Society for the Protection of Nature in Israel, Tel Aviv-Yafo, $318 \mathrm{p}$.

[90] Katuwal, H.B. and Dahal, S. (2013) Golden Jackals in Human Dominated Landscapes of the Manaslu Conservation Area, Nepal. Vertebrate Zoology, 63, 329-334.

[91] Kellert, S.R. (1985) Public Perceptions of Predators, Particularly the Wolf and Coyote. Biological Conservation, 31, 167-189. https://doi.org/10.1016/0006-3207(85)90047-3

[92] Yirga, G., Leirs, H., De Iongh, H.H., Asmelash, T., Gebrehiwot, K., Deckers, J. and Bauer, H. (2016) Spotted Hyena (Crocuta crocuta) Concentrate around Urban Waste Dumps across Tigray, Northern Ethiopia. Wildlife Research, 42, 563-569. https://doi.org/10.1071/WR14228

[93] Seimenis, A. (2008) The Rabies Situation in the Middle East. Developments in Biologicals, 131, 43-53.

[94] David, D. and Yakobson, B.A. (2011) Dogs Serve as a Reservoir and Transmit Rabies in Israel. Is History Repeating Itself? Israel Journal of Veterinary Medicine, 66, 3-8.

[95] Vodopija, R., Racz, A. and Pahor, D. (2016) The Incidence of Jackal Bites and Injuries in the Zagreb Anti Rabies Clinic during the 1995-2014 Period. Acta Clinica Croatica, 55, 151-155. https://doi.org/10.20471/acc.2016.55.01.20

[96] Yom-Tov, Y. (2003) Poaching of Israeli Wildlife by Guest Workers. Biological Conservation, 110, 11-20. https://doi.org/10.1016/S0006-3207(02)00169-6

[97] Gray, T.N.E., Hughes, A.C., Laurance, W.F., Long, B., Lynam, A.J., O’Kelly, H., Ripple, W.J., Seng, T., Scotson, L. and Wilkinson, N.M. (2017) The Wildlife Snaring Crisis: An Insidious and Pervasive Threat to Biodiversity in Southeast Asia. Biodiversity and Conservation, 27, 1031-1037. https://doi.org/10.1007/s10531-017-1450-5

[98] Abd Rabou, A.N. (2020) How Is the COVID-19 Outbreak Affecting Wildlife around the World? Open Journal of Ecology (OJE), 10, 497-517. https://doi.org/10.4236/oje.2020.108032

[99] Bothma, J.P. (2012) Literature Review of the Ecology and Control of the Black-Backed Jackal and Caracal in South Africa. Cape Nature, Bridgetown, 86 p.

[100] Abd Rabou, A.N., Yassin, M.M., Al-Agha, M.R., Hamad, D.M. and Ali, A.S. (2007) The Avifauna of Wadi Gaza Nature Reserve, Gaza Strip-Palestine. The Islamic University Journal (Series of Natural Studies and Engineering), 15, 39-85.

[101] Abd Rabou, A.N., Yassin, M.M., Al-Agha, M.R., Hamad, D.M. and Ali, A.S. (2007) 
The Herpetofauna of the Gaza Strip with Particular Emphasis on the Vicinity of Wadi Gaza. The Islamic University Journal (Series of Natural Studies and Engineering), 15, 111-135.

[102] Abd Rabou, A.N. and Abd Rabou, M.A. (2019) Notes on the Pigeons and Doves (Family Columbidae) Occurring in the Gaza Strip-Palestine. Jordan Journal of Natural History, 6, 30-38.

[103] Abd Rabou, A.N., Musallam, N.J., Musallam, E.J., Elkahlout, K.E., Elnabris, K.J., El-Bashiti, T.A., Abdel Aziz, I.I; Ishneiwra, R.M., Radwan, E.S., Saada, H.S., Shafei, A.A., Fayyad, N.A., Mwafy, S.N., Abu Amra, H.E., Abu Al-Ajeen, R.A., Abu Owda, M.F., Alfarra, R.N., Hassouna, H.A., Hassouna, R.A., Al-Agha, M.R. and Abd Rabou, M.A. (2020) The Palestinian Terrestrial Vertebrate Fauna Preserved at the Biology Exhibitions of the Universities of the Gaza Strip. Research in Ecology, 2, 9-21. https://doi.org/10.30564/re.v2i4.2512

[104] Phillips, R., Gruver, K. and Williams, E. (1996) Leg Injuries to Coyotes Captured in Three Types of Foothold Traps. Wildlife Society Bulletin, 24, 260-263. 